\title{
Regulation of plasminogen activation by TGF- $\beta$ in cultured human retinal endothelial cells
}

\author{
Samantha M Wileman, Nuala A Booth, Norma Moore, Brian Redmill, John V Forrester, \\ Rachel M Knott
}

\begin{abstract}
Backgroundlaims-Regulation of plasmin mediated extracellular matrix degradation by vascular endothelial cells is important in the development of angiogenesis. The aim was to determine whether transforming growth factor (TGF- $\beta$ ) affected the regulation of components of the plasminogen system by human retinal endothelial cells, in order to define more clearly the role of TGF- $\beta$ in retinal angiogenesis in the context of diabetes mellitus. Methods-Human retinal endothelial cells (HREC) were isolated from donor eyes and used between passages $4-8$. The cells were cultured in medium supplemented with $2,5,15$, or $25 \mathrm{mM}$ glucose, plus or minus TGF- $\beta$ ( $1 \mathrm{ng} / \mathrm{ml})$. The concentrations of tissue plasminogen activator $(t-$ $P A)$, urokinase plasminogen activator ( $u-$ PA), and plasminogen activator inhibitor type 1 (PAI-1) in cell conditioned medium were determined by ELISA and the level of PAI-1 mRNA was determined using northern hybridisation. Cell associated plasminogen activity was determined using a clot lysis assay and a chromogenic assay.
\end{abstract}

Results-Under basal conditions (5 $\mathrm{mM}$ glucose), HREC produced PAI-1, t-PA, and trace amounts of u-PA. Cell surface plasminogen activation observed by lysis of fibrin or by cleavage of chromogenic substrate, was mediated by t-PA. Glucose at varying concentrations (2-25 $\mathrm{mM})$ had no significant effect on t-PA mediated clot lysis. In contrast, treatment with TGF- $\beta$ resulted in increased synthesis of PAI-1 protein and mRNA. The increased expression of the PAI-1 mRNAs by TGF- $\beta$ did not occur uniformly, the $2.3 \mathrm{~kb}$ mRNA transcript was preferentially increased in comparison with the $3.2 \mathrm{~kb}$ mRNA $(\mathbf{p}<0.05)$.

Conclusions-These data demonstrate that TGF- $\beta$ increases PAI- 1 and decreases cell associated lysis. This is sufficient to decrease the normal lytic potential of HREC.

(Br F Ophthalmol 2000;84:417-422)

Retinal angiogenesis is characteristic of the most severe stage of diabetic retinopathy (DR)-namely, proliferative diabetic retinopathy (PDR) ${ }^{1-3} \mathrm{~A}$ number of different factors have been implicated in the mechanism of new vessel growth, including specific growth factors, ${ }^{4-6}$ glucose control, ${ }^{78}$ and the balance of the components of the fibrinolytic system. ${ }^{9} 10$

The role of growth factors in the development and increasing severity of DR has been demonstrated by many different studies. ${ }^{41-15}$ However, no single factor has been identified as the causative agent in this process. It is likely that it is the balance of growth promoting and growth reducing factors, and the responsiveness of cells to these factors, which results in a net growth of retinal endothelial cells. ${ }^{16}$

The balance of tissue plasminogen activator (t-PA), urokinase (u-PA), and plasminogen activator inhibitor (PAI-1) determines the generation of plasmin, which has been proposed to facilitate cell migration by degradation of extracellular matrix (ECM) ${ }^{17} \mathrm{PAI}-1$ is a major biosynthetic product of cultured retinal microvascular endothelial cells ${ }^{18}$ and has been shown to be increased in the retina of patients with diabetes. ${ }^{19}$ Components of the fibrinolytic system have been implicated in angiogenesis and are regulated by the concentration and activation of specific growth factors ${ }^{19}{ }^{20}$ and the concentration of glucose to which the cells are exposed. $^{21}$ Further association between the level of PAI-1 and diabetic retinopathy is shown by genotypic studies of patients with type II diabetes, where the presence of $4 \mathrm{G} / 5 \mathrm{G}$ promoter allele of the PAI-1 gene was found to be associated with an increase in the incidence of DR. ${ }^{22}$

Previous studies have demonstrated the importance of transforming growth factor type beta (TGF- $\beta$ ) as a potent regulator of extracellular matrix (ECM) production, ${ }^{23}$ cell proliferation, ${ }^{25}$ and vessel maturation. ${ }^{26}$ Thus, the known role of TGF- $\beta$ in matrix proteolysis in other cell types, ${ }^{27}$ combined with the reported elevation of TGF- $\beta$ in the plasma of patients with type 2 diabetes, suggests the involvement of TGF- $\beta$ in retinal neovascularisation. ${ }^{28}$ Furthermore, a glucose dependent modulation of TGF- $\beta$ production by human retinal endothelial cells ${ }^{29}$ and TGF- $\beta$ levels in the plasma of patients with type 2 diabetes has been demonstrated. ${ }^{28}$ It has also been proposed that the deficient activation of TGF- $\beta$ that occurs in active proliferative diabetic retinopathy and in hypoxic angiogenesis may be a consequence of blood-retinal barrier breakdown and influx of $\alpha_{2}$ antiplasmin from serum. ${ }^{30}$ Therefore, the lack of inhibition of endothelial cell growth that characterises proliferative diabetic retinopathy may be a central component in the process of neovascularisation.
Accepted for publication 29 November 1999 

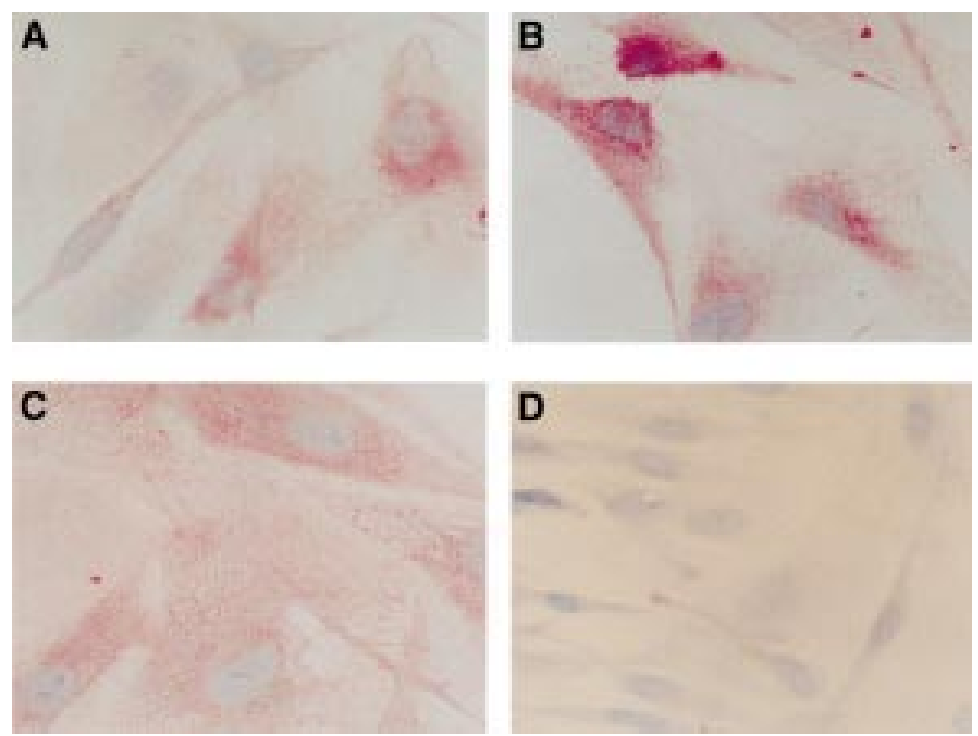

Figure 1 Immunohistochemical detection of $u-P A, t-P A$, and PAI-1 in human retinal endothelial cells. The detection of $u-P A, t-P A$, and PAI-1 was carried out using the APAAP method with HREC cultured in $5 \mathrm{mM}$ glucose, $2.5 \%$ PDS in chamber slides. Positive staining was evident as pink coloration in the cytoplasm with u-PA (A), $t-P A(B)$, and PAI-1 (C). A negative control is shown (D) (original magnification $\times 895$ ).

The expression of t-PA and its inhibitors and the expression of TGF- $\beta$ have been shown to be directly associated with the development of a capillary network. ${ }^{31}$ However, little is known about TGF- $\beta$ mediated regulation of t-PA activity in the retinal endothelium and, thus, the mechanism of retinal neovascularisation. In this study, we have examined the relation between glucose concentration and the production of u-PA, t-PA, and PAI-1 in human retinal endothelial cells (HREC) and the role of TGF- $\beta$ in this process. The use of HREC overcomes the problem of species and tissue specific variability that is encountered by extrapolating from studies on other endothelial cells.

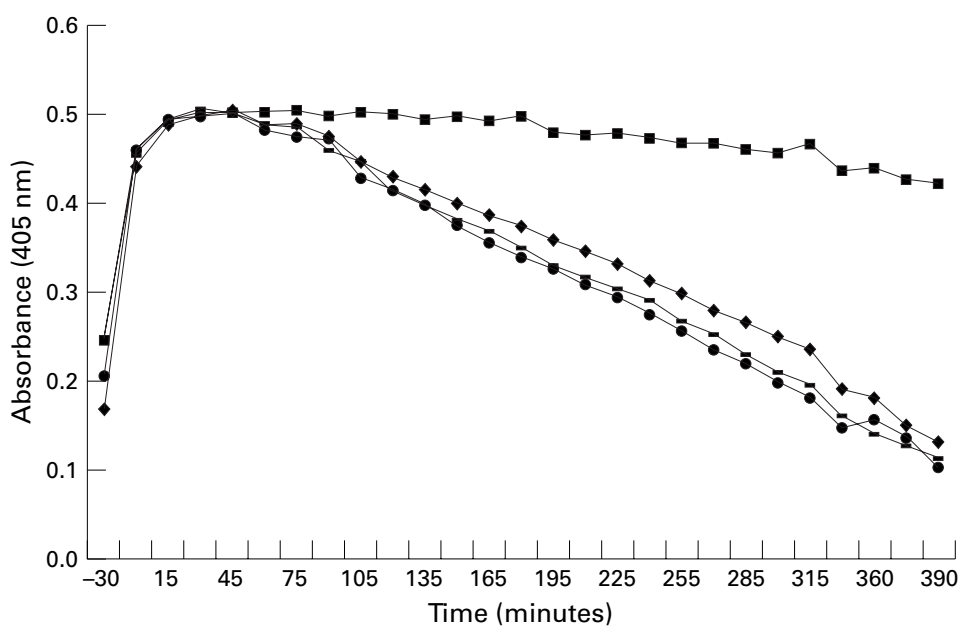

Figure 2 Fibrin clot lysis by HREC. Standard clots, which were prepared with either no antibodies $(\bullet)$ or antibodies to $u-P A(-), t-P A(\bullet)$, and $P A I-1(\bullet)$, were overlaid on monolayers of HREC, pretreated in serum free containing medium supplemented with 5 $m M$ glucose for 24 hours. Results are representative of three experiments using HREC from different donors. The presence of antibodies to t-PA significantly inhibited clot lysis.

\section{Methods}

CELL CULTURE

HREC were isolated from donor eyes, cultured as previously described. ${ }^{32}$ Briefly, the retinas were removed from each eye and homogenised in glucose free Glasgow's minimal essential medium (GMEM). The homogenate was filtered and digested with collagenase $(0.2$ $\mathrm{U} / \mathrm{ml}$ ) before seeding onto fibronectin coated tissue culture plates in GMEM, supplemented with $5 \mathrm{mM}$ glucose and $2.5 \%(\mathrm{v} / \mathrm{v})$ platelet deprived serum (PDS). HREC were routinely used between passages 4 and 8 . All isolates were characterised by their expression of von Willebrand factor (vWF). ${ }^{33}$ On reaching confluence cells were seeded into $75 \mathrm{~cm}^{2}$ flasks for RNA studies, 96 well plates for fibrin clot lysis and ELISA studies, and eight well chambers for immunohistochemistry. Before any experiment the cells were stepped down overnight $(>12$ hours) in glucose free and serum free GMEM. The cells were then treated with varying concentrations of glucose $(2-25 \mathrm{mM})$, plus or minus TGF- $\beta(1 \mathrm{ng} / \mathrm{ml})$ as specified in individual experiments.

IMMUNOHISTOCHEMISTRY

HREC were grown in eight well chamber slides for 24 hours in $5 \mathrm{mM}$ glucose. The monolayers were then washed three times with phosphate buffered saline (PBS), air dried, and fixed in acetone. Immunoreactivity to t-PA, u-PA, and PAI-1 was detected using alkaline phosphatase anti-alkaline phosphatase (APAAP) staining as previously described. ${ }^{34}$ Cells were incubated with the primary antibody-namely, t-PA $\left(\mathrm{ESP}_{-} 5^{35}\right)$, u-PA (MUK-1, Biopool, Sweden), or PAI- $1^{36}$ at a concentration of $10 \mu \mathrm{g} / \mathrm{ml}$ for 1 hour. Immunoreactivity was detected using streptavadin-biotin with alkaline phosphatase (Dako K391) as described by the manufacturers. The cells were counterstained in haematoxylin for 10 seconds, rinsed in Scott's tap water, and mounted in Apathy's aqueous medium with a glass cover slip. Negative controls were included by replacing the primary or secondary antibodies with TRIS buffered saline (TBS) or by using a mouse monoclonal antibody to glucose oxidase from Aspergillus niger (Dako) in place of the primary antibody.

PAI-1, t-PA, AND u-PA ANTIGEN ASSAYS

The concentrations of PAI-1, t-PA, and u-PA in cell culture supernatants were determined by enzyme linked immunosorbent assays (ELISA). The ELISA for PAI-1 is sensitive to $30 \mathrm{pg} / \mathrm{ml}$ and measures both free and complexed forms of PAI-1 to the same extent. ${ }^{37}$ The ELISA for t-PA is sensitive to $50 \mathrm{pg} / \mathrm{ml}$ and detects total t-PA, ${ }^{38}$ while the ELISA for $\mathrm{u}-\mathrm{PA}$ has a detection limit of $0.2 \mathrm{ng} / \mathrm{ml}^{39}$

\section{FIBRIN LYSIS AND CHROMOGENIC ASSAY FOR} PLASMINOGEN ACTIVATOR ACTIVITY

The clot lysis assay was carried out as previously described. ${ }^{40}$ Briefly, HREC were cultured on 96 well plates for 24 hours. Cell monolayers were washed three times with PBS. The cells were then overlaid with fibrinogen 


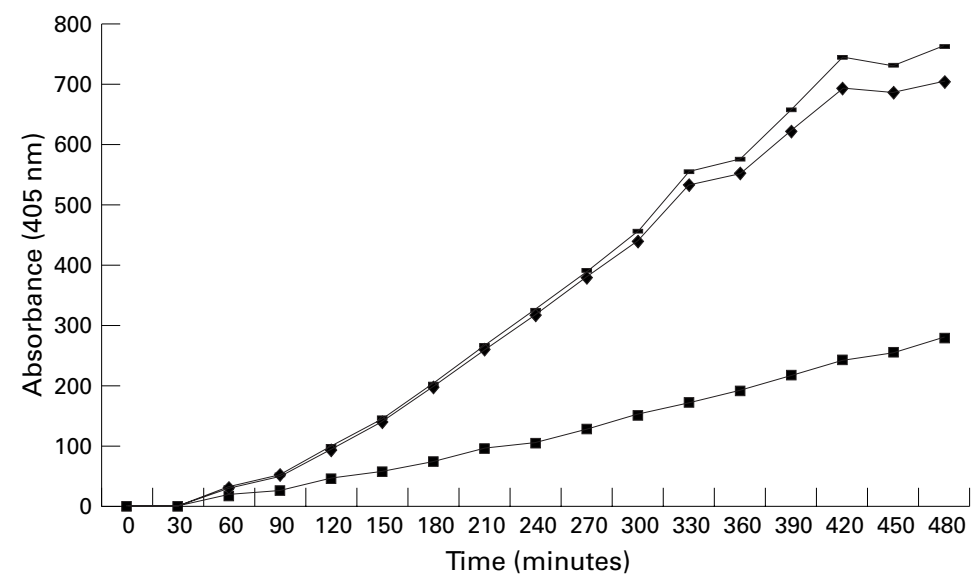

Figure 3 Chromogenic detection of $t-P A$ activity. Monolayers of HREC pretreated for 24 hours in serum free GMEM were incubated with plasminogen and S2251. Incorporation of anti-t-PA (-) significantly reduced the generation of the colour while anti-u-PA (-) had no effect. A negative control using normal rabbit serum $(\diamond)$ is included for comparison.

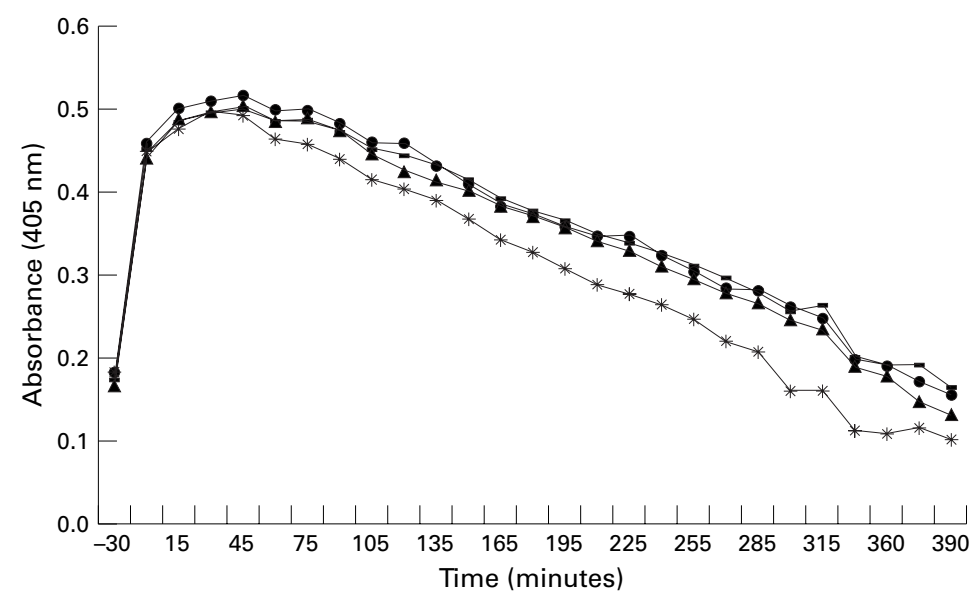

Figure 4 Effects of glucose on HREC fibrin clot lysis. Standard fibrin clots were prepared and overlaid on monolayers of HREC pretreated for 24 hours in serum free containing medium supplemented with $2(\bullet), 5(-), 15\left(^{\star}\right)$, or $25(\mathbf{\Delta}) m M$ glucose. Results are representative of three experiments using HREC from different donors. The rate of clot lysis did not change when the cells were incubated in different glucose concentrations.

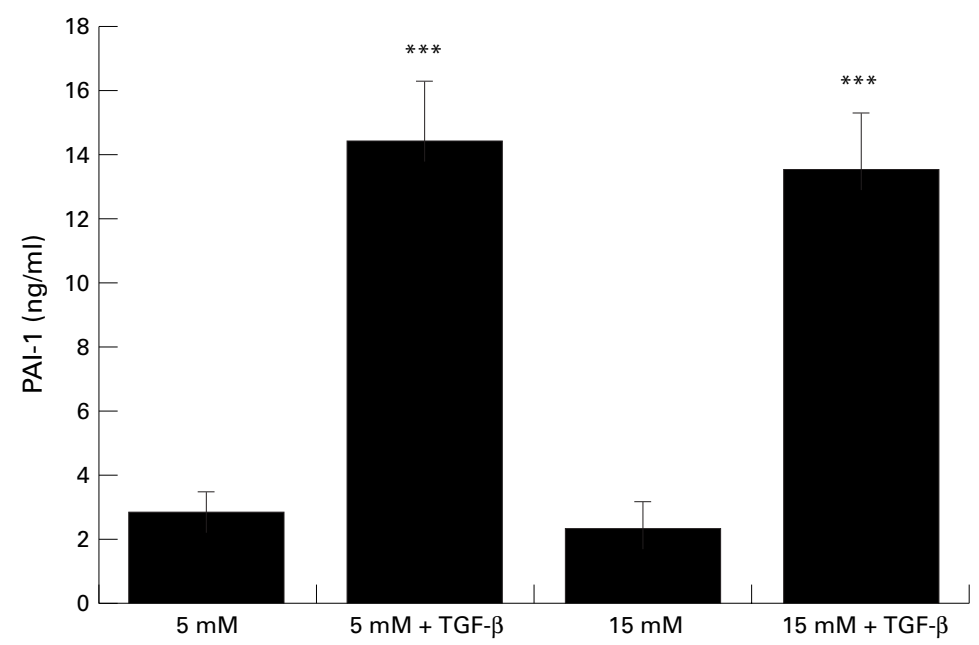

Figure 5 TGF- $\beta$ mediated increased expression of PAI-1 by HREC. HREC were stepped down overnight in serum free glucose free GMEM and then the medium was replaced with 5 or $15 \mathrm{mM}$ glucose plus or minus TGF- $\beta$ (1 ng/ml) for 24 hours. Results are the mean (SD) of six samples from one experiment and are representative of four experiments using HREC from different donors. Increased levels of PAI-1 antigen were evident when the cells were incubated with TGF- $\beta$ as determined by a two tailed Student's test $\left({ }^{\star \star} p<0.001\right)$.
(2.94 $\mu \mathrm{mol} / \mathrm{l})$, to which plasminogen $(0.24$ $\mu \mathrm{mol} / \mathrm{l})$, thrombin $(3.8 \mathrm{nM})$, and calcium (5.3 $\mathrm{mM}$ ) were added (all final concentrations). In particular experiments, IgG preparations of in-house rabbit antibodies raised against t-PA, $\mathrm{u}-\mathrm{PA}$, or PAI- $1^{41}$ were included in the fibrinogen mixture before addition to the wells to give final concentrations of up to $0.25 \mathrm{mg} / \mathrm{ml}$. The microtitre plate was read at $405 \mathrm{~nm}(\mathrm{t}=30$ minutes), using a Titertek Multiskan MCC/ 340 plate reader and incubated at $37^{\circ} \mathrm{C}$ for 30 minutes. Thereafter, the plate was read again $(\mathrm{t}=0)$ and data points were collected at 15 minute intervals for up to 13.5 hours. Control fibrin clots containing t-PA $(0.036 \mathrm{nmol} / \mathrm{l})$ were included in every series of experiments.

HREC, cultured and washed as for the fibrin clot lysis assay, were overlaid with plasminogen and the chromogenic substrate S2251 (Chromogenix) $^{42}$ in PBS to final concentrations of $4 \mu \mathrm{mol} / 1$ and $0.5 \mathrm{mmol} / 1$ respectively. The generation of coloured product at $37^{\circ} \mathrm{C}$ was followed at $405 \mathrm{~nm}$ as above. Antibodies (IgG fraction) were incorporated in particular experiments at concentrations of up to 0.25 $\mathrm{mg} / \mathrm{ml}$.

\section{NORTHERN HYBRIDISATION}

Total RNA was extracted using guanidinium - isothiocyanate - phenol - chloroform ${ }^{43}$ and modified as described. ${ }^{44} \mathrm{~A} 10 \mu \mathrm{g}$ aliquot of the RNA was resolved electrophoretically using a formaldehyde gel, transferred to a nylon membrane (Hybond N, Amersham International, UK) by capillary blotting and cross linked to the membrane using ultraviolet light (Spectrolinker XL-1000, Spectronics Corporation, UK). A cDNA was prepared with a $5 \mu \mathrm{g}$ aliquot of total RNA isolated from cultured HREC using oligo dT (15mer) (Oswell DNA Service, Southampton) and 200 units of reverse transcriptase (M-MLV, Gibco, BRL) as described by the manufacturer. Sequence specific primers for PAI-1 (accession number M16006) (forward primer: gct gac ttc acg agt ctt tca gac caa g; reverse primer: gtg gag act agg gag ttt gac cta aag g) were used. The PCR reaction was carried out as previously described $^{45}$ and the PCR product of $437 \mathrm{bp}$ was resolved electrophoretically on a $1.8 \%$ low melting point agarose gel, excised, purified, and used as a probe for northern hybridisation. The $\beta$-actin cDNA was used as a control for RNA loading. ${ }^{32}$ The relative level of mRNA was determined using GDS5000 Gel Documentation System (UVP Systems Ltd) and is presented as a ratio of PAI- $1 / \beta$-actin mRNA ratio under the respective test conditions.

\section{STATISTICS}

The two tailed Student's $t$ tests for test groups with equal variance and the one tailed Student's $t$ test for comparison against a control of $100 \%$ was used as stated in the text.

\section{Results}

EXPRESSION OF t-PA, u-PA, AND PAI-1 BY HREC HREC stained positively for t-PA, u-PA, and PAI-1 (Fig 1). The t-PA specific staining (B) was located around the perinuclear region with 


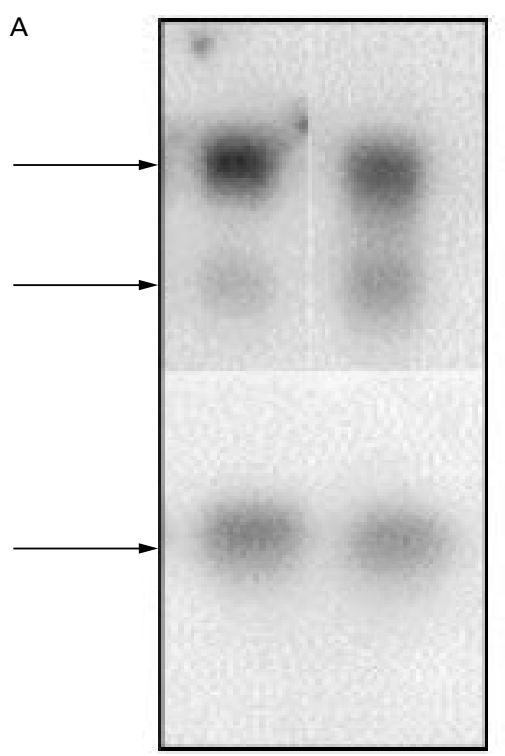

PAI-1

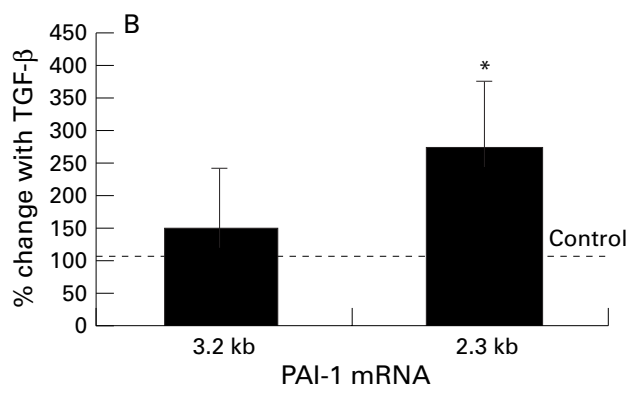

Figure 6 Effect of TGF- $\beta$ on the level of PAI-1 mRNA. HREC were stepped down overnight in serum free glucose free GMEM. The medium was then replaced with serum free GMEM supplemented with $5 \mathrm{mM}$ glucose plus or minus TGF- $\beta$ (1 $\mathrm{ng} / \mathrm{ml})$. After 6 hours' incubation the cells were harvested and total RNA was extracted. Northern hybridisation indicated the presence of two PAI-1 specific $m R N A$ bands (3.2 bp and $2.3 \mathrm{bp}$ ) and $\beta$-actin $m R N A$ (A). The $m R N A$ was quantified and is presented as the mean (SD) of the ratio of the respective PAI-1 transcripts with the level of $\beta$-actin $m R N A$ with data from three separate experiments $(B)$. The results were compared to a value of $100 \%$ - that is, the level of PAI-1 mRNA in the absence of TGF- $\beta$ using a one tailed Student's $t$ test $\left({ }^{*} p<0.05\right)$.

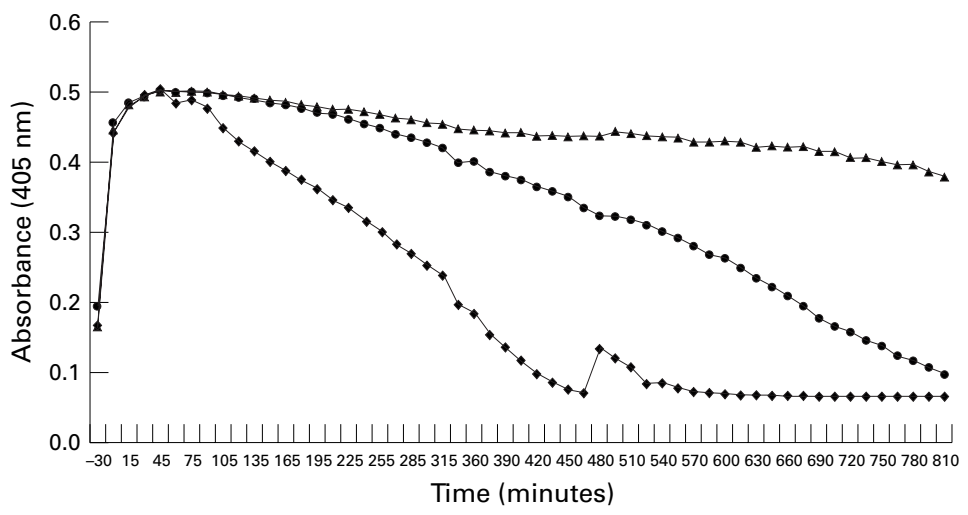

Figure 7 Effects of TGF- $\beta$ treated HREC on fibrin clot lysis. HRECs, pretreated in serum free containing medium with either $5 \mathrm{mM}$ glucose ( $\bullet$ or $5 \mathrm{mM}$ glucose plus TGF- $\beta$ (1 $n g / m l(\boldsymbol{\Lambda})$ for 24 hours, were overlaid with fibrin. Antibody to PAI-1 was incorporated in the fibrin overlay of the TGF- $\beta$ treated HREC $(\bullet)$. Results are representative of three experiments using different donors. The presence of TGF- $\beta$ increased the rate of clot lysis and this effect was partially inhibited by the presence of antibody to PAI-1. a high level of variability between cells. The majority of the HREC (>95\%) were positively stained for u-PA (A), while for the PAI-1 there was evidence of matrix associated staining in addition to that associated with the cells (C). The relative concentrations of secreted antigen in HREC conditioned medium were as follows: PAI-1 was present in the range of 10-100 $\mathrm{ng} / \mathrm{ml}$, in marked excess over t-PA at $0-5$ $\mathrm{ng} / \mathrm{ml}$, while u-PA was below the limit of detection $(<0.2 \mathrm{ng} / \mathrm{ml})$.

Washed cells were examined for their ability to lyse fibrin and thus for the balance of PA and PAI-1. Spontaneous lysis of fibrin occurred in 6-7 hours (Fig 2). Lysis was inhibited by antibodies to t-PA, while normal rabbit IgG had no effect. Antibodies to u-PA did not inhibit lysis nor did antibodies to PAI-1 enhance it. These data show that cell associated fibrinolytic activity in untreated HREC was due to t-PA. In addition, the t-PA activity of washed cells was not affected by secreted PAI-1. This was confirmed using a chromogenic assay, where the generation of coloured product using the substrate S2251 was significantly inhibited by anti-t-PA while there was no effect in the presence of anti-u-PA (Fig 3).

\section{EFFECT OF GLUCOSE}

HREC were treated with varying concentrations of glucose $(2-25 \mathrm{mM})$ for 24 hours and the effects of these glucose concentrations were examined. Changes in glucose concentration produced only minor changes in the levels of t-PA or PAI-1 proteins secreted by HREC as determined by ELISA. Examination of earlier time points were also examined (2 and 6 hours) and also revealed no evidence of any glucose specific changes in these antigens. The fibrin clot lysis assay was also used to investigate the effect of glucose treatment (2-25 mM) on HREC. Similar clot lysis activity was seen with all glucose concentrations, with $50 \%$ lysis being achieved in 4 hours (Fig $4)$.

EFFECT OF TGF- $\beta$ ON PAI-1 AND CLOT LYSIS

TGF- $\beta$ ( $1 \mathrm{ng} / \mathrm{ml})$ significantly increased the concentration of PAI- 1 in cell culture conditioned medium after 24 hours as determined using a two tailed Student's $t$ test $(\mathrm{p}<0.001$; Fig 5). The increased level of PAI-1 was also evident by zymography of culture medium as previously described ${ }^{41}$ (data not shown). There was no difference in PAI-1 between cells cultured in 5 and $15 \mathrm{mM}$ glucose. Moreover the cells responded similarly to the presence of TGF- $\beta$ in these different glucose concentrations with a sevenfold increase in PAI-1 (Fig 5). The increased PAI-1 antigen was preceded by a significant increase in the smaller PAI-1 mRNA isoform $(p<0.05)(2.3 \mathrm{~kb})$ at 6 hours in the presence of TGF- $\beta$. In contrast, the level of the $3.2 \mathrm{~kb}$ mRNA did not change significantly (Fig 6). Furthermore, a change in cell associated plasmin activity was evident when cells were cultured in the presence of TGF- $\beta$ (Fig 7) with very little plasminogen activation being observed (Fig 7). Some activity was generated in the presence of a neutralising antibody to 
PAI-1. The effect of this antibody, even at high concentrations, was incomplete. This is presumably due to increased synthesis of PAI-1 resulting in the partial conversion of t-PA to t-PA-PAI-1 complex on the cell surface before the addition of antibody.

\section{Discussion}

This study demonstrates that TGF- $\beta$ mediated increase in t-PA levels in HRECs is regulated at the level of PAI-1 mRNA with the 2 mRNAs for PAI-1 being differentially regulated. This finding highlights some key differences between HRECs and other cell types with respect to the mechanism of TGF- $\beta$ mediated regulation, which may in turn provide important insights into the behaviour of the retinal vasculature. Previous work has demonstrated that TGF- $\beta$ binds to the PAI- 1 promoter to induce transcription $^{46}$ and that the two mRNAs are uniformly regulated. ${ }^{47}$ The difference in the size of the mRNA transcripts lies in alternative splicing of the 3 ' untranslated region (UTR). ${ }^{48}$ The change in mRNA level is likely to result from a change in the stability of one of the mRNAs, as the 3' UTR is known to have a key role in mRNA stability. ${ }^{49}$ Differential mRNA stability has previously been noted for PAI-1 mRNA in response to other growth factors. Insulin increases the half life of the $3.2 \mathrm{~kb}$ PAI-1 mRNA, while IGF-1, alone or with insulin, markedly prolongs the half lives of both species..$^{50}$ The increased level of the smaller mRNA species seen with TGF- $\beta$ in this study illustrates the potential for a further level regulation by growth factors, although a more detailed investigation of steady state mRNA levels would be required to elucidate the precise mechanisms that are involved.

The apparent lack of an effect on the production or activity of t-PA or PAI-1 with increased glucose concentration by HREC, contrasts markedly with the findings with human umbilical vein endothelial cells where high glucose concentrations significantly increased t-PA and PAI-1 expression..$^{51}{ }^{52}$ However, this was evident after chronic exposure to high concentrations of glucose in contrast with the relatively short duration of incubation in the present study. Chronic exposure of the vascular endothelium to high levels of glucose is known to increase PAI-1 and attenuate t-PA via glycation of low density lipoproteins. ${ }^{53}$ Furthermore, the effect of high glucose concentration may be indirect in that the conditions may activate other factors that subsequently regulate the components of the fibrinolytic system. For example, we have previously demonstrated that changes in glucose concentration regulate the expression of TGF- $\beta$ in both HREC ${ }^{29}$ and in peripheral blood leucocytes, ${ }^{45}$ which may in turn increase the synthesis of PAI- 1 .

It is well established that microvascular endothelial cells are a major source of t-PA, in contrast with macrovascular cells. ${ }^{54}$ This study demonstrated cell associated t-PA activation as the major plasminogen activator in HREC. ${ }^{55}$ The mechanism of regulation of the plasminogen system by TGF- $\beta$ in the human retinal endothelium is similar to that reported for renal glomerular cells ${ }^{27}$ and bovine aortic endothelial cells (BAEC). ${ }^{47}$ The activity of t-PA is regulated by PAI-1 and is a key modulator of ECM proteolysis. Clearly, PAI-1 has a key role in t-PA mediated lysis in response to TGF- $\beta .^{56}$ The increased levels of PAI- 1 in the retina of individuals with diabetes, ${ }^{19}$ and the increased levels of TGF- $\beta$ that have been found in people with diabetes, ${ }^{28}$ are therefore likely to be significant to the pathological signs of diabetic retinopathy. We did observe a degree of variability between the different cell lines with respect to the levels of t-PA and PAI-1 production by ELISA and by immunohistochemistry, that is likely to reflect the various donors that were used. Similar observations have been made in other primary cells. ${ }^{27}{ }^{57}$ It should be noted, however, that diabetic donors were not used in this study as it has already been reported that HREC from patients with diabetes differ in their production of t-PA and PAI- $1 . .^{55}$

Although a more chronic exposure to glucose does reflect the situation in patients with diabetes it is unclear at what stage in diabetic retinal disease that the regulation of components of the fibrinolytic system become significant. Increased deposition of ECM is characteristic of the early stages of $\mathrm{DR}^{58}$ and the increased levels of PAI-1 in the retina of patients with diabetes ${ }^{19}$ may lead to this. The consequence of increased ECM deposition and the concomitant increased capillary leakage results in the deposition of components of the fibrinolytic system and their subsequent accumulation in the basement membrane. ${ }^{59}$ This may have an important role in t-PA activity in the process of neovascularisation that characterises proliferative diabetic retinopathy.

Significantly increased PAI-1 caused by glucose/diabetes may promote the persistence of vascular clots and thus ischaemia. This is not counteracted by increased t-PA; thus, there is no regulatory mechanism to assist or counterbalance the increased level of t-PA and fibrinolysis. Induction of the growth factor TGF- $\beta$ compounds this problem since it increases PAI-1 but does not affect t-PA. Further, more detailed studies are now required to extend our understanding of fibrinolysis within the retinal endothelium and, thus, the mechanism of diabetes mediated retinal damage.

We thank Ian MacGregor for generous provision of antibodies to t-PA.

1 Baudouin C, Fredj-Reygrobellet D, Lapalus P, et al. Immunohistopathologic findings in proliferative diabetic retinopathy. Am f Ophthalmol 1988;105:383-8.

2 Olk RJ, Lee CM. Classification of diabetic retinopathy. In: Olk RJ, Lee CM, eds. Diabetic retinopathy: practical management.1st ed. Philadelphia: JB Lippincott, 1993:320.

3 Aiello LP, Gardner TW, King GL, et al. Diabetic retinopathy. Diabetes Care 1998;21:S47-9.

4 Boulton M, Gregor Z, McLeod D, et al. Intravitreal growth factors in proliferative diabetic retinopathy: correlation with neovascular activity and glycaemic management. Brf Ophthalmol 1997;81:228-33.

5 Forrester JV, Shafiee A, Schroder S, et al. The role of growth factors in proliferative diabetic retinopathy. Eye 1993; 7: 276-87.

6 Patel B, Hiscott P, Chateris D, et al. Retinal and preretinal localisation of epidermal growth factor, transforming growth factor alpha, and their receptor in proliferative diabetic retinopathy. Brf Ophthalmol 1994;78:714-18. 
7 Shamoon H. The relationship of glycaemic exposure $(\mathrm{HbA} 1 \mathrm{c})$ to the risk of development and progression of retinopathy in the Diabetes Cont

8 Diabetes Control of Complications Trial Group. The effect of intensive treatment of diabetes on the development and progression of long-term complications in insulindependent diabetes mellitus. N Engl F Med 1993;329:97786.

9 Ostermann H, Tschope D, Greber W, et al. Enhancement of spontaneous fibrinolytic activity in diabetic retinopathy. Thromb Haem 1992;68:400-3.

10 Grant MB, Ellis EA, Caballero S, et al. Plasminogen activator inhibitor-1 overexpression in nonproliferative diabetic retinopathy. Exp Eye Res 1996;63:233-44.

11 D'Amore PA. Mechanisms of retinal and choroidal neovascularization. Invest Ophthalmol Vis Sci 1994;35:3974-8.

12 Forrester JV, Knott RM, Olson J, et al. Growth factors and diabetic retinopathy. Diabet Rev Int 1997;6:9-12.

13 Pfeiffer A, Spranger J, Meyer-Schwickerath R, et al. Growth factor alterations in advanced diabetic retinopathy: a possi-
ble role of blood retina barrier breakdown. Diabetes 1997; role of $26-30$

14 Tanihara $\mathrm{H}$, Inatani $\mathrm{M}$, Honda $\mathrm{Y}$. Growth factors and their receptors in the retina and pigment epithelium. Progr Ret Eye Res 1997;16:271-301.

15 Wiedemann P. Growth factors in retinal diseases: proliferative vitreoretinopathy, proliferative diabetic retinopathy and retinal degeneration. Surv Ophthalmol 1992;36:373-84.

16 Alder VA, Su E-M, Yu D-Y, et al. Diabetic retinopathy: early functional changes. Clin Exp Pharmacol Physiol 1997;24: $785-8$.

17 Booth NA. The natural inhibitors of fibrinolysis. In: Bloom AL, Forbes CD, Thomas DP, Tuddenham EGD, eds. Haemolysis and thrombogenesis. 3rd ed. Edinburgh: Churchill Livingstone, 1994:699-717.

18 Canfield AE, Schor AM, Loskutoff DJ, et al. Plasminogen activator inhibitor-type I is a major biosynthetic product of retinal microvascular endothelial cells and pericytes in culretinal microvascular endothelial cell
ture. Biochem 7 1989;259:529-35.

19 Elias AN, Pandian MR, Naqvi F, et al. Relationship between prorenin, IGF-I, IGF-binding proteins and retinopathy in diabetic patients. Gen Pharmacol 1996;27:329-32.

20 Presta M, Rusnati M, Maier JAM, et al. Basic fibroblast growth factor and endothelial cells: receptor interaction, signal transduction, cellular response-dissociation of the mitogenic activity of bFGF from its plasminogen activatorinducing capacity. In: Maragoudakis ME, Gullino P, Lelkes PE, eds. Angiogenesis in health aand disease.1st ed. New York: Plenum Press, 1992:79-89.

21 Vaag A, Hother-Nielsen O, Skott P, et al. Effect of acute hyperglycaemia on glucose metabolism in skeletal muscles in IDDM patients. Diabetes 1992;41:174-82.

22 Nagi DK, McCormack LJ, Mohamed-Ali V, et al. Diabetic retinopathy, promoter $(4 \mathrm{G} / 5 \mathrm{G})$ polymorphism of PAI-1 gene, and PAI-1 activity in Pima indians with type 2 diabetes. Diabetes Care 1997;20:1304-9.

23 Baricos WH, Cortez SL, Deboisblanc M, et al. Transform ing growth factor-beta is a potent inhibitor of extracellular matrix degradation by cultured human mesangial cells. $\mathcal{F}$ matrix degradation by cultured

24 Ignotz RA, Massague J. Transforming growth factor-beta stimulates the expression of fibronectin and collagen and their incorporation into the extracellular matrix. $f$ Bio Chem 1986;261:4337-45.

25 Liu G, Takano T, Amino N. TGF-beta1 inhibits the cell proliferation stimulated by IGF-I by blocking the tyrosine phosphorylation of $175 \mathrm{kDa}$ substrate. Endocrin Res 1996; 22:277-87.

26 Massague J. The transforming growth factor-beta family. Anпu Rev Cell Biol 1990;6:597-641.

27 Wilson HM, Reid FJ, Brown PAJ, et al. Effect of transforming growth factor-betal on plasminogen activators and plasminogen activator nhibitor-1 in renal glomerular cells. Exp Nephrol 1993;1:343-50.

28 Pfeiffer A, Middelberg-Bisping K, Drewes C, et al. Elevated plasma levels of transforming growth factor-betal in plasma levels of transforming growth

29 Pascal MM, Forrester JV, Knott RM. Glucose-mediated regulation of transforming growth factor beta (TGF-beta) and TGF-beta receptors in human retinal endothelial cells. Curr Eye Res 1999;19:162-70.

30 Spranger J, Meyer-Schwickerath R, Klein M, et al. Deficient activation and different expression of transforming growth factor-beta isoforms in active proliferative diabetic retinopathy and neovascular eye disease. Exp Clin Endocrino Diabetes 1999;107:21-8.

31 Ito K-I, Ryuto M, Ushiro S, et al. Expression of tissue-type plasminogen activator and its inhibitor couples with development of capillary network by human microvascular endothelial cells on matrigel. F Cell Physiol 1995;162:21324.

32 Knott RM, Robertson M, Muckersie E, et al. Regulation of glucose transporters (GLUT-1 and GLUT-3) in human retinal endothelial cells. Biochem $f$ 1996;318:313-17.

33 Sehested M, Hou-Jensen K. Factor VIII realted antigen as an endothelial cell marker in benign and malignant diseases. Virchows Arch 1981;391:217-25.

34 Robbie LA, Bennett B, Croll AM, et al. Proteins of the fibrinolytic system in human thrombi. Thromb Haem 1999;75: 127-33.
35 MacGregor IR, Micklem LR, James K, et al. Characterisation of epitopes on human tissue plasminogen activator recognised by a group of monoclonal antibodies. Thromb Haem 1985;53:45-50.

36 MacGregor IR, Tonner AM, Micklem LR, et al. Murine monoclonal antibodies against active site epitopes on human endothelial plasminogen activator inhibitor (PAI1). Fibrinolysis 1990;4:27-34.

37 MacGregor IR, Booth NA. An enzyme linked immunosorbent assay (ELISA) used to study the cellular secretion of endothelial plasminogen activator inhibitor (PAI-1). Thromb Haem 1988;59:68-72.

38 MacGregor IR, MacDonald S, Dawes J, et al. A monoclonal antibody enzyme linked immunosorbent assay (ELISA) directed towards a fibrin binding region of tissue-type plasminogen activator. Fibrinolysis 1987;1:247-52.

39 Jackson MR, Moore NR, Ritchie $\mathrm{H}$, et al. Enhanced cell associated u-PA activity of endothelial cells in response to soluble factors released by human peripheral blood monocytes. Blood Coag Fibrin 1996;7:728(Abstract).

40 Ritchie H, Robbie LA, Kinghorn S, et al. Monocyte plasminogen activator inhibitor 2 (PAI-2) inhibits u-PAmediated fibrin clot lysis and is cross-linked to fibrin. Thromb Haem 1999;81:96-103.

41 Booth NA, MacGregor IR, Hunter NR, et al. Plasminogen activator inhibitor from human endothelial cells: purification and characterization. Eur f Biochem 1987;165:595600.

42 Chmielewska J, Wiman B. Determination of tissue plasminogen activator and its fast inhibitor in plasma. Clin Chem 1986;32:482-5.

43 Chomczynski P, Sacchi N. Single-step method of RNA isolation by acid guanidinium thiocyanate-phenol-chloroform extraction. Anal Biochem 1987;162:156-9.

44 Knott RM, Robertson M, Forrester JV. Regulation of glucose transporter (GLUT3) and aldose reductase mRNA in bovine retinal endothelial cells and retinal pericytes in high glucose and high galactose culture. Diabetologia 1993;36:808-12.

45 Knott RM, Pascal MM, Ferguson C, et al. Regulation of transforming growth factor-beta (TGF- $\beta$ ), basic fibroblast growth factor (bFGF) and vascular endothelial cell growth factor (VEGF) messenger RNA in peripheral blood leucocytes in patients with diabetic retinopathy. Metabol Clin Exp 1999;48:1-8.

46 Hua X, Liu X, Ansari DO, et al. Synergistic cooperation of TFE3 and Smad proteins in TGF-beta-induced transcription of the plasminogen activator inhibitor-1 gene. Genes $\mathcal{E}$ Development 1998;12:3084-95.

47 Sawdey M, Podor TJ, Loskutoff DJ. Regulation of type 1 plasminogen activator inhibitor gene expression in cultured bovine aortic endothelial cells. Induction by transforming growth factor-beta, lipopolysaccharide, and tumor necrosis factor-alpha. F Biol Chem 1989;264:10396-401.

48 Ginsburg D, Zeheb R, Yang AY, et al. cDNA cloning of human plasminogen activator-inhibitor from endothelial cells. 7 Clin Invest 1986;78:1673-80

49 Nielson DA, Shapiro DJ. Insights into hormonal control of messenger RNA stability. Mol Endocrinol 1990;4:953-7.

50 Fattal PG, Schneider DJ, Sobel BE, et al. Posttranscriptional regulation of expression of plasminogen activator inhibitor type $1 \mathrm{mRNA}$ by insulin and insulin-like growth factor 1. F Biol Chem 1992;267:12412-15.

51 Maiello M, Boeri D, Podesta F, et al. Increased expression of tissue plasminogen activator and its inhibitor and reduced fibrinolytic potential of human endothelial cells cultured in elevated glucose. Diabetes 1992;41:1009-15.

52 Cagliero E, Roth T, Taylor AW, et al. The effects of high glucose on human endothelial cell growth and gene expression are not mediated by transforming growth factor-beta. $L a b$ Invest 1995;73:667-73.

53 Zhang J, Ren S, Sun D, et al. Influence of glycation on LDLinduced generation of fibrinolytic regulators in vascular endothelial cells. Arterioscler Thromb Vasc Biol 1998;18: $1140-8$

54 Levin EG, Santell L, Osborn KG. The expression of endothelial tissue plasminogen activator in vivo: a function defined by vessel size and anatomic location. F Cell Sci 1997;110:139-48.

55 Grant MB, Guay C. Plasminogen activator production by human retinal endothelial cells of nondiabetic and diabetic origin. Invest Ophthalmol Vis Sci 1991;32:53-64.

56 Handt S, Jerome WG, Braaten JV, et al. PAI-1 released from cultured human endothelial cells delays fibrinolysis and is incorporated into the developing fibrin clot. Fibrinolysis 994;8:104-12

57 Ritchie H, Jameson A, Booth NA. Thrombin modulates synthesis of plasminogen activator inhibitor type 2 by human peripheral blood monocytes. Blood 1995;86:342835.

58 Forrester JV, Knott RM. Pathogenesis of diabetic retinopathy and cataract. In: Pickup JC, Williams G, eds. Textbook of diabetes. 2nd ed. Oxford: Blackwell Science, 1997:451-470.

59 Ashton NA. Vascular basement membrane changes in diabetic retinopathy. Br F Ophthalmol 1974;58:344-66. 